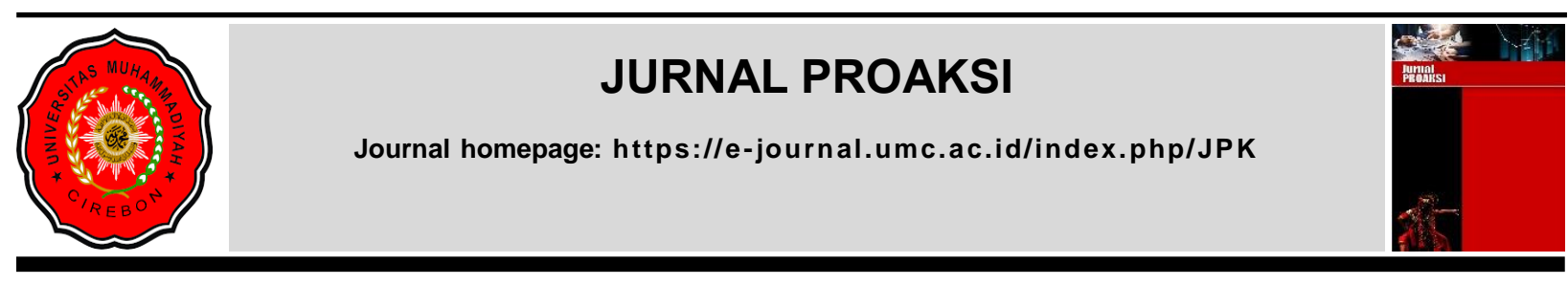

\title{
PERAN KEARIFAN LOKAL DALAM MEWUJUDKAN AKUNTABILITAS PENGELOLAAN KEUANGAN DESA
}

\author{
Widiana Riska Wulandari ${ }^{1}$ \\ Aprina Nugrahesty Sulistya Hapsari ${ }^{2 *}$ \\ ${ }^{1}$ Fakultas Ekonomika dan Bisnis, Universitas Kristen Satya Wacana \\ Email :232017123@ student.uksw.edu \\ ${ }^{2}$ Fakultas Ekonomika dan Bisnis, Universitas Kristen Satya Wacana \\ *Corresponden Author Email : aprina@uksw.edu
}

Diterima : 26 April 2021

Direvisi : 24 Mei 2021

Dipublikasikan : 17 Oktober 2021

\begin{abstract}
Abstrak
Penggelontoran dana desa yang besar dan terus meningkat dari tahun ke tahun nyatanya tidak sejalan dengan pengelolaan dana desa yang baik, hal ini terbukti dari ditemukannya penyelewengan dana desa yang terjadi di berbagai daerah hal ini dikarenakan salah satunya akibat kurangnya akuntabilitas pengelolaan dana desa. Penelitian ini bertujuan untuk mengeksplorasi peran kearifan lokal dalam mewujudkan akuntabilitas publik di dalam pengelolaan keuangan desa di Desa Kesongo, Kabupaten Semarang. Penelitian ini merupakan penelitian deskriptif kualitatif, sumber data dalam penelitian ini merupakan data primer yang diperoleh melalui wawancara mendalam dengan narasumber dan dokumentasi. Teknik analisis data yang digunakan yaitu reduksi data, penyajian data, dan penarikan simpulan. Hasil dan pembahasan dalam penelitian ini menunjukkan bahwa kearifan lokal di Desa Kesongo mampu untuk mendukung terwujudnya akuntabilitias pengelolaan keuangan desa, hal ini dikarenakan nilai-nilai luhur yang terkandung didalam tradisi-tradisi yang rutin dilaksanakan di Desa Kesongo yaitu sadranan dan merti desa.
\end{abstract}

Kata Kunci : Akuntabilitas, Akuntansi, dan Kearifan Lokal

\section{PENDAHULUAN}

Fenomena yang terjadi saat ini adalah menguatnya tuntutan akuntabilitas oleh masyarakat, baik di pemerintahan pusat maupun daerah, hal ini mengakibatkan akuntabilitas menjadi penting karena mendorong instansi terkait dalam hal ini adalah pemerintah desa untuk melakukan perbaikan tata kelola pemerintahan (Hanum, 2019). Menurut Setiawan, Haboddin, dan Wilujeng, (2017) faktanya akuntabilitas merupakan tujuan tertinggi dari pelaporan keuangan pemerintah. Akuntabilitas pengelolaan keuangan desa selalu menarik untuk dijadikan fenomena, terlebih pemerintah melalui Menteri Dalam Negeri, Tito Karnavian menyampaikan pentingnya menjaga akuntabilitas dana desa dikarenakan akuntabilitas akan mempengaruhi fleksibilitas dan efisiensi penggunaan anggaran dana desa (Akbar, 2020). Hal yang serupa disampaikan oleh Bupati Pandeglang, Irna Narulita yang mengharapkan kepala desa agar lebih transparan dan akuntabel dalam mempertanggungjawabkan dana desa, karena anggaran yang diberikan untuk desa cukup besar (Fachreinsyah, 2020). Akuntabilitas publik terkait pengelolaan keuangan menjadi penting karena dapat meningkatkan kinerja manajerial, salah satunya karena adanya pertanggungjawaban laporan keuangan kepada masyarakat sehingga masyarakat tidak hanya mengetahui anggaran dana melainkan dapat 
mengetahui pula realisasi dari anggaran tersebut yang berakibat pada kinerja pemerintah daerah yaitu melaksanakan tugas secara maksimal karena diawasi oleh masyarakat (Putra, 2013).

Fenomena akuntabilitas pengelolaan keuangan desa juga semakin menjadi penting setelah pemerintah terus berkomitmen meningkatkan jumlah dana desa dari tahun ke tahun, yaitu mulai dari tahun 2015 sampai sekarang, sebesar 2,86\% yaitu dari Rp70 triliun pada tahun 2019 menjadi Rp72 triliun pada tahun 2020. Tujuan adanya penggelontoran dana desa ini yaitu untuk meningkatkan kesejahteraan masyarakat, namun pada pelaksanaannya masih belum efektif, salah satu indikatornya adalah masih banyaknya penyelewengan dana desa yang terjadi. Hal ini disebab kan karena kurangnya pemahaman atau integritas dalam mengelola dana keuangan serta kurangnya pengawasan yang mengakibatkan laporan keuangan menjadi tidak akuntabel, serta menimbulkan celah untuk oknum-oknum pemerintah daerah dalam melakukan kecurangan, seharusnya dengan adanya kenaikan penggelontoran dana desa diimbangi dengan akuntabilitas yang baik (Yulianah, 2017).

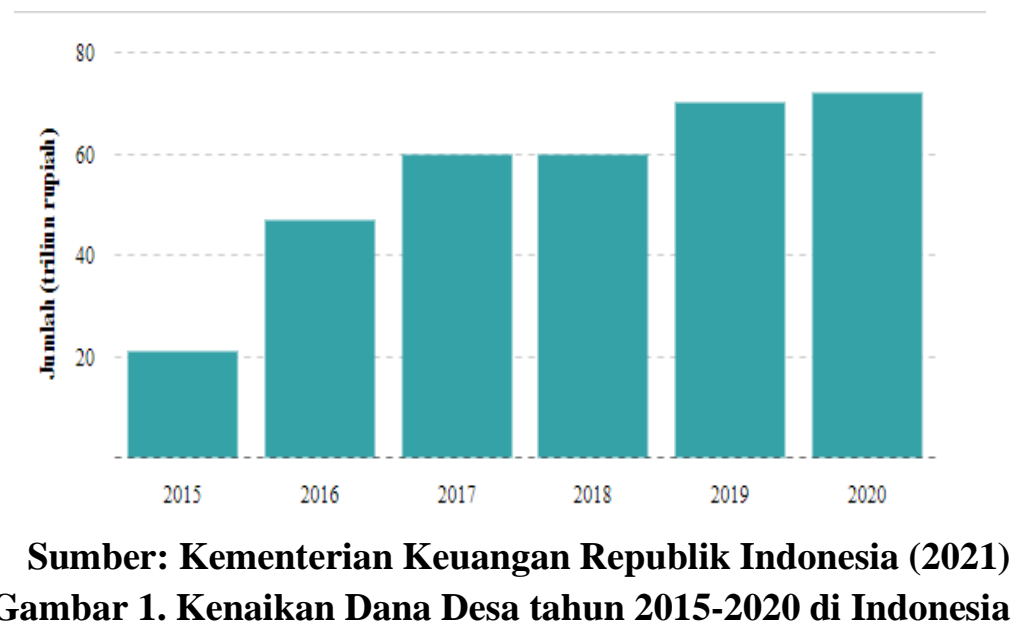

Pentingnya akuntabilitas pengelolaan keuangan desa nyatanya tidak dijiwai dengan sempurna yang terbukti dari adanya beberapa kasus penyelewengan dana desa, seperti kasus yang baru-baru ini terjadi akibat terjadinya Pandemi Covid-19 penggelapan dana BLT (Bantuan Langsung Tunai) bagi masyarakat yang berdampak akibat pandemi Covid-19 di Desa Darul Aman, Riau (Indriani, 2020). Penyelewengan dana desa juga terjadi di Bangka Belitung yaitu terdapat seorang bendahara yang melakukan kegiatan fiktif dalam pembelian ATK dan Perjalanan bisnis senilai Rp. 260,7 Juta (Dahnur, 2020). Selain itu, telah terjadi pula penyelewengan yang dilakukan oleh Kepala Desa Karyajaya, Kabupaten Garut, penyelewengan yang dilakukan yaitu pemalsuan pertanggungjawaban, terdapat kegiatan fiktif yang mengakibatkan kerugian negara sebesar Rp. 400 juta lebih (Karang, 2020). Hal serupa juga terjadi di Desa Matang Ulim, Kabupaten Aceh Utara, Kepala Desa melakukan penggelapan dana desa sejak tahun 2017 senilai Rp325 juta (Masriadi, 2020).

Penggelapan uang yang dilakukan oleh Kepala Desa juga terjadi di Desa Wonosido, Kabupaten Pekalongan, penggelapan uang tersebut senilai Rp292 juta (Sarono, 2020). Maraknya kecurangan yang terjadi saat ini akibat kurangnya pengetahuan, pengawasan dan kurangnya akuntabilitas pada Laporan keuangan, hal ini juga disampaikan oleh Wibisono (2017) dalam penelitiannya bahwa telah terjadi banyak kasus korupsi maupun suap yang dilakukan oleh kepala desa, hal ini mengakibatkan kerugian keuangan negara dan juga meresahkan masyarakat.

Peran kearifan lokal dalam memitigasi risiko kecurangan dilakukan oleh Permata dan Hapsari (2020) di Desa Lerep, Kabupaten Ungaran, hasil dari penelitian ini adalah tidak ditemukan potensi kecurangan dalam pengelolaan dana desa di Desa Lerep, hal ini dikarenakan masih kuatnya kearifan lokal berupa tradisi-tradisi yang rutin dilakukan, dalam tradisi tersebut mengandung nilai-nilai luhur yang positif. Hal tersebut senada dengan penelitian yang dilakukan oleh Latuconsina dan Soleman (2019) yaitu nilai- 
nilai yang terkandung dalam kearifan lokal terbukti dapat mencegah tindakan kecurangan, kearifan lokal disini seperti petuah/ungkapan, legenda kebijaksanaan dan simbol adat seperti Rumah tua/Raja yang didalamnya terkandung nilai tanggung jawab, kehormatan, kepemilikan dan kekeluargaan.

Penelitian terkait konsep akuntabilitas dalam pengelolaan keuangan desa dilakukan oleh Nafidah dan Anisa (2017) di Kabupaten Jombang, yang memberikan hasil bahwa pengelolaan keuangan desa di Desa Sumbermulyo, Kabupaten Jombang telah dilaksanakan secara akuntabel sesuai dengan indikator akuntabilitas yang ditetapkan. Senada dengan penelitian yang dilakukan oleh Nafidah dan Anisa (2017), penelitian yang dilakukan oleh Wida, Supatmoko, dan Kurrohman (2017) di desa-desa Kabupaten Banyuwangi menunjukkan bahwa pengelolaan Alokasi Dana Desa di 9 Dea Kecamatan Rogojampi, Kabupaten Banyuwangi telah dilaksanakan secara akuntabel. Kendala terwujudnya akuntabilitas pengelolaan keuangan desa, ditunjukkan melalui penelitian yang dilakukan oleh Riyanto (2015) dengan hasil pengelolaan Alokasi Dana Desa dapat dipertanggungjawabkan kepada seluruh pemerintah desa, namun belum bisa dipertanggungjawabkan kepada semua masyarakat desa, faktor penghambat akuntabilitas finansial dalam pengelolaan Alokasi Dana Desa salah satunya adalah karena adanya aturan baru dari Badan Permusyawaratan Desa (BPD) sedangkan faktor pendukungnya adalah tingginya partisipasi masyarakat dalam pembangunan.

Penelitian ini bertujuan untuk mengeksplorasi peran kearifan lokal dalam mewujudkan akuntabilitas publik di dalam pengelolaan keuangan desa di Desa Kesongo, Kabupaten Semarang. Berbeda dengan penelitian sebelumnya, penelitian ini lebih berfokus pada peran kearifan lokal yang berada di Desa Kesongo yaitu Tradisi sadranan dan Merti Desa yang dikaitkan dengan perwujudan akuntabilitas pengelolaan keuangan desa, selama ini kearifan lokal sering kali dikaitkan dengan mitigasi kecurangan atau peran kearifan lokal dalam membentuk budaya organisasi. Melalui wawancara awal di Desa Kesongo ini masih kental akan kebudayaan jawa seperti merti desa, sadranan dan rewang yang dilakukan ketika ada masyarakat yang sedang mengadakan suatu acara yang dilaksanakan secara rutin.

Visi dari Kabupaten Semarang yaitu "Terwujudnya Kabupaten Semarang Mandiri, Tertib, Sejahtera (MATRA)", serta salah satu misinya adalah "menciptakan pemerintahan yang katalistik dan dinamis dengan mengedepankan prinsip good governance didukung kelembagaan yang efektif dan kinerja aparatur yang kompeten, serta pemanfaatan teknologi informasi”, sehingga penelitian ini bertujuan untuk menyelaraskan visi dan misi Kabupaten Semarang yaitu prinsip good governance yang salah satunya terkait dengan akuntabilitas. Penelitian ini diharapkan dapat bermanfaat bagi pemerintah desa yaitu sebagai bahan evaluasi untuk menilai kearifan lokal yang membudaya didalam masyarakat apakah mampu untuk membantu mengarahkan perilaku masyarakat dalam kaitannya dalam mewujudkan prinsip akuntabilitas dalam pengelolaan keuangan dana desa, dan dapat dijadikan sebagai pengembangan literatur terkait dengan konsep akuntabilitas publik dan kearifan lokal dalam perspektif akuntansi bagi akademisi.

\section{KAJIAN PUSTAKA \\ Teori Stakeholder}

Teori Stakeholder menyatakan bahwa perusahaan bukan merupakan entitas yang beroperasi untuk kepentingan individu atau kelompok namun harus memberikan manfaat pula bagi stakeholder, teori ini menekankan bahwa berjalannya kegiatan perusahaan karena dukungan dari stakeholder maka dari itu perlu mempertimbangkan persetujuan dari stakeholder dalam setiap pengambilan keputusan (Deegan, Rankin, \& Voght, 2000). Teori Stakeholder merupakan bagian dari konsep manajemen strategis yang bertujuan untuk membantu perusahaan mempertahankan relasi dengan kelompok eksternal serta mengembangkan keunggulan kompetitif (Mardikanto, 2014). Freeman (1984) menyatakan bahwa seluruh stakeholder adalah "pelanggan" maksudnya adalah para pemangku kepentingan berhak untuk mengetahui dana yang sudah diberikan digunakan sudah sesuai dengan yang seharusnya atau belum dalam hal ini adalah dana yang sudah diberikan kepada pemerintah pusat kepada pemerintah daerah. Teori stakeholder berhubungan dengan tindakan organisasi dalam mempertanggungjawabkan suatu aktivitas yang telah dilaksanakan kepada stakeholder, sehingga dapat membantu menginterpretasikan peran akuntabilitas dalam suatu organisasi (Gray, Dey, Owen, Evans, \& Zadek, 1997). 
Penelitian ini menggunakan dasar Teori Stakeholder dari Deegan et al (2000) karena menegaskan bahwa berjalannya perusahaan bukan hanya untuk kepentingan pribadi atau kelompok namun harus bermanfaat pula bagi pemangku kepentingan yaitu merupakan pihak yang memberikan dukungan sehingga perusahaan dapat berjalan dengan baik, yang dimaksud pemangku kepentingan dalam penelitian ini adalah pemerintah pusat, sehingga pemerintah daerah harus menyajikan laporan keuangan yang dapat dipertanggungjelaskan kepada pemerintah pusat, karena berjalannya pemerintahan daerah membutuhkan dukungan penuh dari pemerintah pusat sehingga kepentingan dari pemerintah pusat dan pemerintah daerah dapat bersinergi.

\section{Akuntabilitas}

Menurut Peraturan Pemerintah Republik Indonesia Nomor 101 (2000) pemerintahan dikatakan baik apabila pemerintah yang dapat mengembangkan serta menerapkan prinsip profesionalitas, akuntabilitas, transparansi, pelayanan prima, demokrasi, efisiensi, efektifitas, supremasi hukum dan dapat diterima oleh seluruh masyarakat, hal itu di diwujudkan dengan prinsip serta asas-asas good governance. Good Governance adalah pelayanan publik yang efisien, sistem pengadilan yang dapat diandalkan serta pemerintahan yang bertanggungjawab (accountable) pada publiknya (Zeyn, 2011). Terwujudnya good governance dapat didukung dengan menerapkan prinsip good governance yaitu transparan, akuntabel, partisipatif dan dilakukan secara tertib melalui disiplin anggaran (Astuti \& Yulianto, 2016).

Akuntabilitas selalu erat kaitannya dengan Akuntansi karena akuntabilitas berperan dalam penyusunan laporan keuangan guna memberikan laporan keuangan yang dapat dipahami oleh seluruh pihak mengenai aktivitas yang telah dilaksanakan. Akuntabilitas menurut Lestari, Atmaja, dan Adipura (2014) adalah kewajiban dalam mempertanggungjawabkan oleh pihak yang membuat laporan keuangan secara jelas kepada orang yang berkepentingan serta laporan keuangan akan lebih baik apabila akurat, handal dan tepat waktu maksudnya dalam penelitian ini adalah kewajiban yang harus dilaksanakan oleh pemerintah daerah kepada pemerintah pusat serta masyarakat dalam mempertanggungjawabkan penggunaan keuangan dana desa dalam aktivitas yang telah dilaksanakan dalam bentuk laporan keuangan yang akurat, handal, dan tepat waktu. Sedangkan akuntabilitas menurut Harjito, Wibowo, dan Suhardjanto (2016) adalah para pengambil keputusan yaitu pengurus bertanggungjawab kepada individu maupun lembaga yang berkepentingan, akuntabilitas juga menjadi salah satu prinsip pemerintahan yang berhubungan dengan pertanggungjawaban atas pengambilan keputusan oleh pemimpin kepada pihak yang berkepentingan.

Akuntabilitas adalah pertanggungjelasan atau dalam hal ini adalah pertanggungjawaban atas keberhasilan ataupun kegagalan dalam pelaksanaan misi untuk mencapai visi organisasi. (Utami, 2019). Menurut Mardiasmo (2002) akuntabilitas adalah kewajiban agen dalam mempertanggungjawabkan, menyajikan, melaporkan serta mempaparkan seluruh aktivitas yang telah dilaksanakan kepada principal. Akuntabilitas juga dibedakan menjadi dua jenis yaitu Akuntabilitas Vertikal (Internal) dan Akuntabilitas Horizontal (Eksternal), akuntabilitas vertikal merupakan pertanggungjawaban kepada kekuasaan yang lebih tinggi yang dilaksanakan oleh setiap lapisan organisasi internal atas pengelolaan dana. Sedangkan akuntabilitas horizontal adalah pertanggungjawaban seluruh amanat yang telah dilaksanakan untuk disampaikan kepada pihak eksternal dalam hal ini adalah masyarakat luas.

Menurut beberapa definisi akuntabilitas tersebut penelitian ini menggunakan definisi akuntabilitas menurut Utami (2019) yaitu berfokus terhadap pertanggungjelasan laporan keuangan suatu organisasi dalam pelaksanaan misi untuk mencapai visi organisasi serta dalam penelitian ini menggunakan indikator akuntabilitas meliputi perencanaan, pelaksanaan, penatausahaan, pelaporan, serta pertanggungjawaban pengelolaan keuangan dana desa Kesongo, Kecamatan Tuntang.

\section{Kearifan Lokal}

Kearifan lokal merupakan ilmu pengetahuan yang digunakan sebagai pedoman hidup yang berupa kegiatan yang dilaksanakan oleh masyarakat setempat, dalam bahasa asing kearifan lokal juga dikenal dengan istilah "local wisdom" yaitu pengetahuan setempat, "local knowledge" yaitu keberadaan setempat atau "local genius" yaitu kecerdasan setempat. Kearifan lokal adalah kecerdasan masyarakat yang didapatkan melalui pengalaman yang mengandung nilai-nilai yang melekat didaerah tertentu (Rahyono, 2009). Menurut Koentjaraningrat (2009) kearifan lokal diklasifikasikan sebagai aktivitas sosial yang 
tertuang dalam kebudayaan, yaitu pengetahuan yang dijadikan patokan pandangan hidup dalam bentuk tindakan yang dilakukan sehari-hari. Sedangkan menurut Umarmi dan Amiruddin (2014) kearifan lokal merupakan suatu sistem kepercayaan, norma, hukum dan budaya yang dituangkan dalam bentuk kebudayaan secara turun-temurun, pengetahuan tersebut digunakan sebagai pedoman hidup dalam suatu daerah.

Kearifan Lokal adalah ide gagasan suatu lingkungan sekitar yang bersifat bijaksana, yang penuh dengan keistimewaan, bernilai positif, yang turun-temurun dan dilaksanakan oleh seluruh masyarakat (Sartini, 2004). Kearifan lokal menurut Musafiri, Utaya, dan Astina (2016) adalah nilai baik yang berada di dalam masyarakat dan ditanamkan kepada remaja dalam rangka pencegahan dampak globalisasi. Sedangkan menurut Sibarani (2012) kearifan lokal adalah nilai yang sudah lama ada dan terus berkembang di dalam suatu wilayah dengan nilai budaya yang digunakan sebagai pedoman hidup. Penelitian ini menggunakan definisi kearifan lokal yang telah dipaparkan oleh Harjito et al. (2016) yaitu Kearifan lokal adalah produk budaya masa lalu yang terbentuk karena keunggulan budaya masyarakat secara turuntemurun dan dijadikan sebagai pedoman hidup, karena tingkah laku masyarakat dapat dipengaruhi oleh budaya masyarakat.

Kearifan lokal berbeda-beda antara daerah satu dengan yang lainnya di Jawa Tengah terdapat kearifan lokal seperti iriban, merti desa, dan sadranan. Terdapat beberapa nilai luhur yang terkandung dalam kearifan lokal tersebut untuk iriban sendiri mengandung nilai kejujuran, disiplin, kesederhanaan, tanggung jawab, kepedulian dan keadilan. Fenomena kecurangan sebagai akibat adanya pengelolaan yang tidak akuntabel nyatanya dapat dimitigasi melalui peran kearifan lokal yang mengandung nilai-nilai luhur, seperti tradisi iriban ini merupakan tradisi selamatan yang dilakukan ketika akan menanam padi agar ketika musim panen mendapatkan hasil panen yang melimpah, makna yang terkandung dalam tradisi iriban ini merupakan warga desa berharap semoga dijauhkan dari segala hal buruk sehingga membentuk sikap kehatihatian serta tidak ingin melakukan hal-hal buruk, seperti kecurangan dan korupsi, sehingga tradisi ini diharapkan mampu menumbuhkan sikap jujur kepada seluruh warga masyarakat (Permata \& Hapsari, 2020). Kearifan lokal mengandung nilai yang dapat membentuk perilaku dalam setiap individu (Sukmayadi, 2017). Nilai kearifan lokal juga dapat mempengaruhi tata kelola pemerintahan yang baik sehingga dapat tercapai keadilan ekonomi bagi seluruh masyarakat, sehingga kearifan lokal dapat berperan didalam perilaku setiap individu dalam berorganisasi (Rahmatiani, 2016).

Di Jawa Tengah selain tradisi Iriban juga terdapat tradisi Merti desa mengandung nilai kejujuran dan kerja keras, kepedulian, serta kedisiplinan, sedangkan sadranan mengandung nilai keberanian, kesederhanaan, kepedulian, keadilan dan mandiri (Permata \& Hapsari, 2020). Berbeda dengan kearifan lokal di Jawa Tengah, di Jawa Timur memiliki kearifan lokal yang unik pula seperti lumbung desa yang merupakan tradisi yang sudah ada sebelum perang dunia II, yaitu pada musim panen petani menyimpan sebagian hasil panennya di lumbung desa yang akan digunakan nanti ketika musim paceklik (Harjito et al., 2016). Di Bali memiliki keunikannya sendiri yaitu konsep tri hita karana yang mengandung nilai kebersamaan, keselarasan, keseimbangan antara tujuan ekonomi, pelestarian lingkungan dan budaya, serta estetika dan spiritual (Saputra, Sujana, \& Tama, 2018).

Menurut beberapa definisi Kearifan Lokal diatas penelitian ini menggunakan definisi kearifan lokal menurut Harjito et al (2016) yaitu yaitu Kearifan lokal merupakan produk budaya masa lalu yang terbentuk karena keunggulan budaya masyarakat secara turun-temurun dan dijadikan sebagai pedoman hidup, karena tingkah laku masyarakat dapat dipengaruhi oleh budaya masyarakat. Dalam penelitian ini mengangkat Kearifan Lokal yang berada di Desa Kesongo yaitu Tradisi Sadranan dan Merti Desa, Sadranan sendiri merupakan tradisi masyarakat islam jawa dalam rangka menyambut bulan Ramadhan dengan melakukan ziarah kubur kepada leluhur, yakni membersihkan makam dan mendoakan arwah leluhur yang telah meninggal, hal ini juga sebagai pengingat bahwa manusia tidak akan selamanya hidup melainkan akan ada saatnya mengalami kematian (Pemerintah Desa Sumberagung, 2017). Sedangkan, Merti Desa merupakan sedekah sebagai ucapan syukur atas limpahan rezeki yang sudah Tuhan Yang Maha Esa berikan (Permata \& Hapsari, 2020). 


\section{Pengelolaan Keuangan Desa}

Undang-Undang Republik Indonesia Nomor 6 (2014) "Desa adalah kesatuan masyarakat hukum yang memiliki batas wilayah yang berwenang untuk mengatur dan mengurus urusan pemerintahan, kepentingan masyarakat setempat berdasarkan prakarsa masyarakat, hak asal usul, dan/atau hak tradisional yang diakui dan dihormati dalam sistem pemerintahan Negara Kesatuan Republik Indonesia". Sehingga Desa diberi kewenangan untuk mengelola pemerintahannya sendiri termasuk dalam hal keuangan, namun fenomena yang ada saat ini pengelolaan keuangan dana desa masih belum dimanfaatkan secara maksimal, hal ini dibuktikan dengan banyaknya kasus kecurangan yang terjadi, untuk menekan tindakan kecurangan dana desa maka dana desa perlu dikelola dengan baik, salah satu caranya adalah dengan menerapkan asas pengelolaan keuangan desa yang tertuang dalam Peraturan menteri dalam negeri Republik Indonesia nomor 20 (2018) yang berbunyi "Keuangan Desa dikelola berdasarkan asas transparan, akuntabel, partisipatif serta dilakukan dengan tertib dan disiplin anggaran”. Keuangan Desa yaitu hak segala sesuatu dapat berupa barang maupun uang yang merupakan hak dan kewajiban desa yang berhubungan dengan pelaksanaan hak dan kewajiban Desa itu sendiri.

Menurut Peraturan Pemerintah nomor 60 (2014) diketahui bahwa penggelontoran dana ke desa bersumber dari Alokasi Dana Desa (ADD), dana desa yang bersumber dari Anggaran Pendapatan dan Belanja Negara (APBN) diberikan dalam bentuk Anggaran Pendapatan dan Belanja Daerah (APBD) Kabupaten/Kota yang kemudian dana desa tersebut digunakan untuk penyelenggaraan pemerintahan, pelaksanaan pembangunan, pembinaan masyarakat serta pemberdayaan masyarakat. Tujuan dari penggelontoran dana desa adalah untuk mewujudkan pertumbuhan ekonomi di Indonesia serta meratakan pendapatan, sedangkan indikator keberhasilan dana desa tercermin dalam pembangunan dan kesejahteraan masyarakat.

Penelitian ini menggunakan definisi Pengelolaan Keuangan Desa menurut Peraturan menteri dalam negeri Republik Indonesia nomor 20 (2018) yaitu seluruh aktivitas yang meliputi perencanaan, pelaksanaan, penatausahaan, pelaporan, dan pertanggungjawaban keuangan Desa, karena aktivitas tersebut sesuai dengan tahapan pengelolaan dana Desa Kesongo. Tahap perencanaan dilaksanakan dengan membuat anggaran yang dibutuhkan untuk satu periode tertentu, hal ini merupakan salah satu upaya agar penggunaan keuangan dana desa dapat berjalan dengan efektif dan efisien. Tahap yang kedua yaitu pelaksanaan, pada tahap ini merupakan tahap implementasi dari apa yang sudah direncanakan pada tahap perencanaan yaitu rangkaian kegiatan yang dilaksanakan dalam satu periode. Tahap selanjutnya adalah penatausahaan, di tahap penatausahaan ini seluruh transaksi yang dilakukan selama masa periode dicatat sesuai dengan prinsip, standar, dan prosedur yang berlaku secara aktual dan faktual. Tahap yang terakhir adalah pelaporan dan pertanggungjawaban pada tahap ini bendahara desa menyusun laporan keuangan sebagai bentuk pertanggungjawaban yang dilampiri dokumen-dokumen terkait seperti nota dan kuitansi.

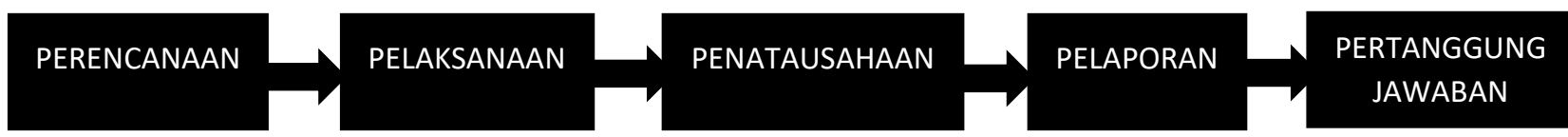

Sumber : Peraturan menteri dalam negeri Republik Indonesia nomor 20 (2018) Gambar 2. Tahapan Pengelolaan Keuangan Desa

\section{METODE PENELITIAN}

\section{Jenis Penelitian dan Teknik Pengumpulan Data}

Penelitian ini menggunakan metode penelitian deskriptif kualitatif dengan objek penelitian di Desa Kesongo, Kecamatan Tuntang, Kabupaten Semarang. Penelitian ini menggunakan teknik pengumpulan data berupa wawancara dan dokumentasi. Jenis data dalam penelitian ini merupakan data primer yang didapat melalui wawancara serta data sekunder yang diperoleh dari dokumentasi terkait dari dokumendokumen desa berupa laporan keuangan, Rancangan Kerja Pemerintah (RKP) Desa, Anggaran Pendapatan dan Belanja (APB) Desa. Narasumber dalam penelitian ini adalah perangkat desa, Badan Permusyawaratan 
Desa (BPD), serta tokoh masyarakat. Berikut merupakan Struktur Organisasi dari masing-masing narasumber :

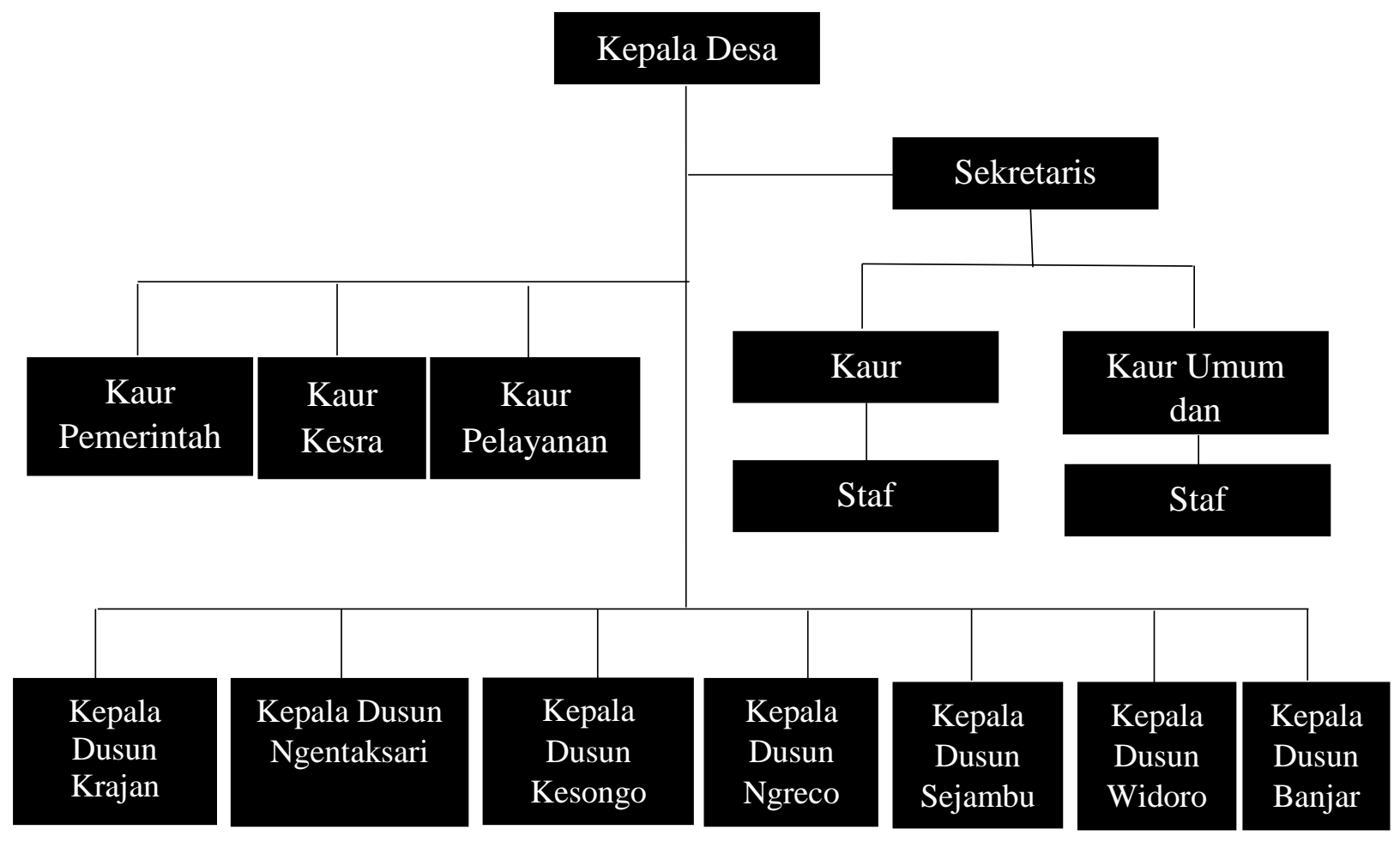

Gambar 3. Struktur Organisasi Pemerintah Desa Kesongo

Pemerintahan desa merupakan salah satu komponen yang sangat penting bagi berjalannya suatu negara karena pemerintahan desa merupakan bagian kecil dari roda pemerintahan. Dalam penelitian ini dibutuhkan informasi mengenai pengelolaan keuangan desa kesongo yang selama ini telah dilaksanakan serta terkait dengan akuntabilitas desa kesongo yang didapat dengan wawancara dengan salah satu perangkat Desa Kesongo yaitu sekretaris Desa Kesongo, adapun tugas dari sekretaris desa adalah bersama dengan kepala desa mempersiapkan serta melaksanakan pengelolaan administrasi desa, mempersiapkan bahan penyusunan laporan penyelenggaraan pemerintah desa.

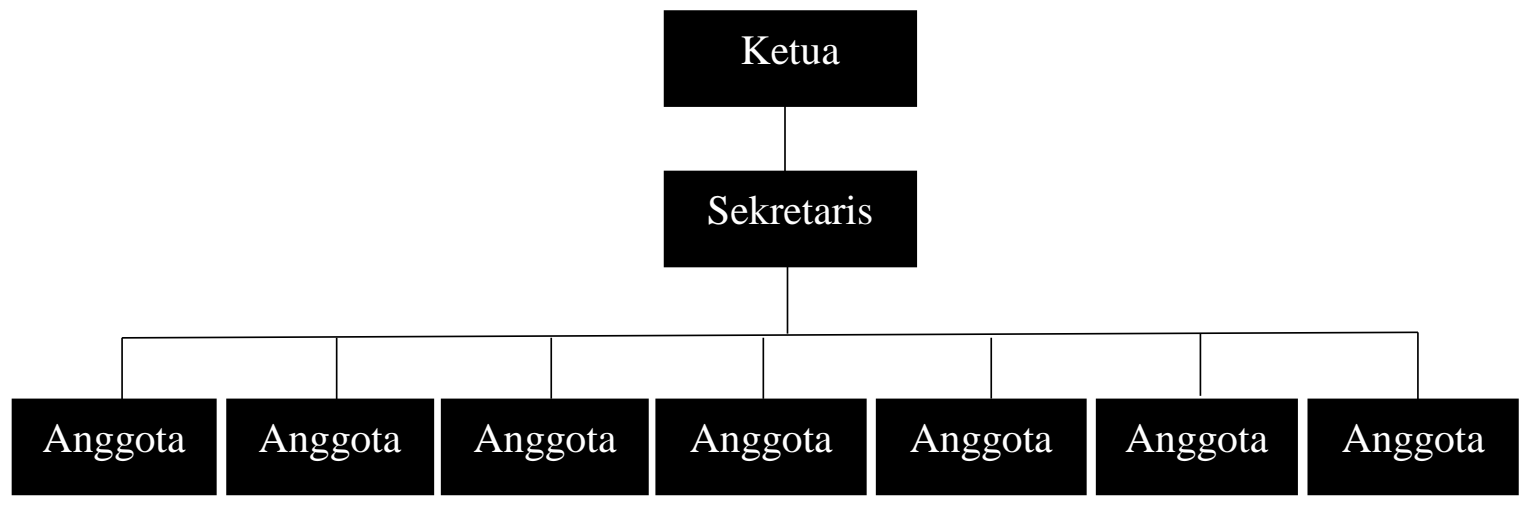

Gambar 4. Struktur Organisasi BPD Desa Kesongo 
Badan Permusyawaratan Desa (BPD) memiliki peran penting karena sebagai wadah bagi masyarakat desa kesongo untuk menampung aspirasi untuk mendukung penyelenggaraan pemerintahan desa, selain itu BPD juga memiliki wewenang dalam membentuk peraturan desa yang merupakan produk hukum tertinggi pada tingkat pemerintahan desa.

\section{Tahapan Penelitian}

Penelitian ini mengumpulkan data melalui wawancara dari berbagai narasumber dengan daftar pertanyaan yang telah disiapkan dan dikembangkan sesuai dengan persoalan penelitian. Data yang telah diperoleh kemudian dianalisis menggunakan tiga tahapan analisis antara lain reduksi data, penyajian data, dan penarikan simpulan. Tahap pertama adalah reduksi data, yaitu membuat transkrip wawancara kemudian meringkas dan memilah data yang telah dikumpulkan tersebut menjadi data yang relevan dengan penelitian, dengan cara membuat tabel bantu yang berisi tahapan pengelolaan keuangan desa dan kearifan lokal yang ada di Desa Kesongo yang kemudian dari tahapan tersebut dikaitkan dengan nilai-nilai dari kearifan lokal. Tahap yang kedua adalah penyajian data, yaitu menampilkan data yang telah dibandingkan dengan melihat tabel bantu agar menjadi lebih terorganisir dan mudah dipahami untuk menemukan data terkait kearifan lokal Desa Kesongo dalam mewujudkan akuntabilitas pada proses pengelolaan dana desa yang kemudian dinarasikan dengan mengacu pada kajian pustaka yaitu menggunakan teori stakeholder, konsep akuntabilitas, dan konsep pengelolaan dana desa. Tahap yang terakhir yaitu penarikan simpulan mengenai rumusan peran kearifan lokal dalam perwujudan akuntabilitas keuangan desa yang dilakukan dengan melakukan verifikasi secara berkala selama proses penelitian berlangsung dengan berbagai narasumber yang berbeda maupun waktu yang berbeda, kemudian hasil yang didapat dideskripsikan dalam bentuk narasi. Penelitian ini dalam memeriksa keabsahan data menggunakan teknik triangulasi yaitu dalam menguji keakuratan data dengan melakukan wawancara kepada beberapa narasumber menggunakan pertanyaan yang sama, kemudian dikonfirmasi antara jawaban narasumber yang satu dengan yang lainnya, jika terdapat ketidaksesuaian kemudian dicocokan dengan dokumen yang ada.

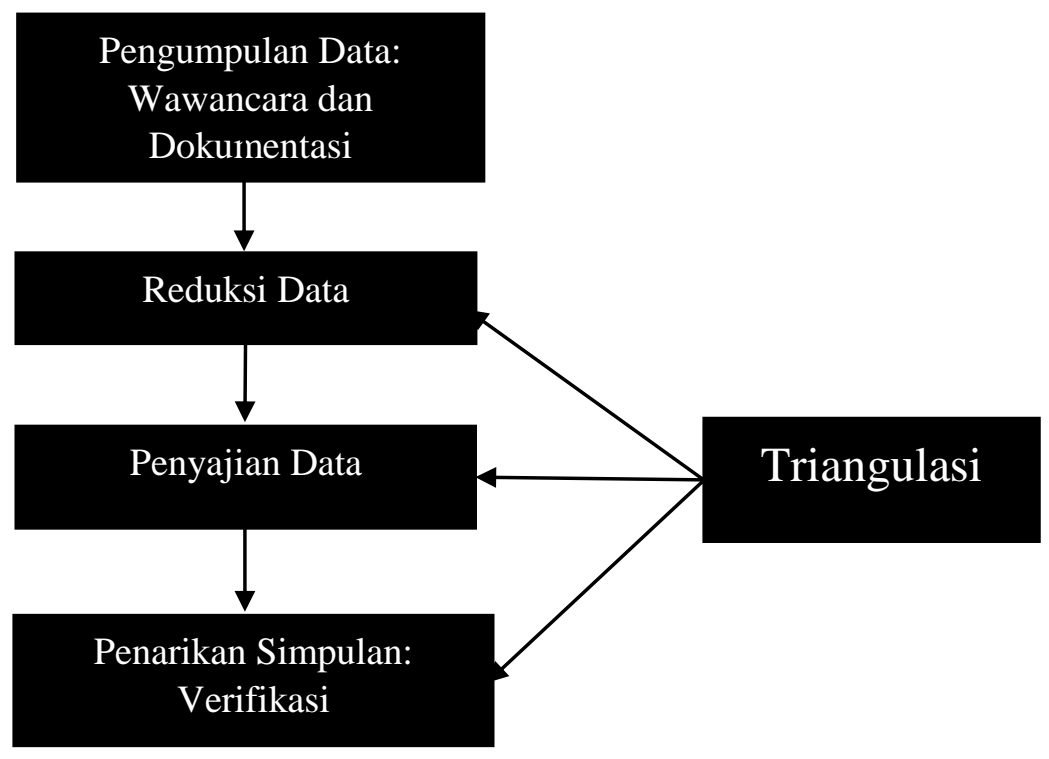

Gambar 5. Teknik Pengumpulan dan Analisis Data

Penelitian ini dalam menganalisis data yang sudah dikumpulkan menggunakan teori stakeholder yaitu tidak hanya menguntungkan individu maupun kelompok namun juga harus menguntungkan stakeholder dalam penelitian ini adalah pihak yang memberikan dukungan yaitu pemerintah pusat sehingga pemerintah daerah harus menyajikan laporan keuangan secara jelas dan akuntabel. Kemudian, penelitian ini juga menganalisis kearifan lokal yang melekat di Desa Kesongo serta perannya dalam mewujudkan akuntabilitas yang berfokus pada pertanggungjelasan laporan keuangan dengan indikator akuntabilitas yang 
tertuang dalam Peraturan menteri dalam negeri Republik Indonesia nomor 20 (2018) meliputi perencanaan, pelaksanaan, penatausahaan, pelaporan dan pertanggungjawaban.

\section{HASIL DAN PEMBAHASAN Gambaran Objek Penelitian}

Desa Kesongo merupakan salah satu desa yang berada di Kecamatan Tuntang, Kabupaten Semarang, Jawa Tengah. Desa Kesongo dikenal dengan desa yang bersih, dan sejuk, hal ini merupakan akibat dari kesadaran masyarakat akan pentingnya menjaga kebersihan serta peran dari BUMDes Desa Kesongo yaitu terkait dengan pengelolaan sampah. Kesadaran masyarakat Desa Kesongo tersebut timbul akibat rasa ewuh-perkewuh atau tenggang rasa yang ditanamkan melalui kearifan lokal yang ada di Desa Kesongo, selain itu Desa Kesongo juga dikenal dengan desa wisata karena keunikan dan keindahan Desa Kesongo.

Jumlah penduduk yang ada di Desa Kesongo yaitu 7.700 jiwa yang terdiri dari 3.850 laki-laki dan 3.850 perempuan. Sebagian besar penduduk Desa Kesongo memeluk agama Islam sebesar 99,3\% yaitu 7.642 jiwa, sementara penduduk yang lain menganut agama Kristen, Katholik dan Budha. Tingkat pendidikan penduduk Desa Kesongo yaitu tidak/belum sekolah sampai dengan strata III dengan angka tertinggi yaitu SD dengan 46,5\% yaitu sebesar 1.176 jiwa. Jenis pekerjaan yang paling banyak dilakukan penduduk Desa Kesongo adalah Pegawai Negeri Sipil yaitu sebanyak 935 Jiwa. Namun, mayoritas penduduk Desa Kesongp merupakan Pelajar/Mahasiswa yaitu sebanyak 1.805 jiwa.

Berikut merupakan penyaluran, penyerapan dana desa di Desa Kesongo tahun 2020 menurut Dinas Pemberdayaan Masyarakat, Desa, Kependudukan dan Pencatatan Sipil Provinsi Jawa Tengah.

Gambar 6. Penyaluran, Penyerapan Dana Desa di Desa Kesongo

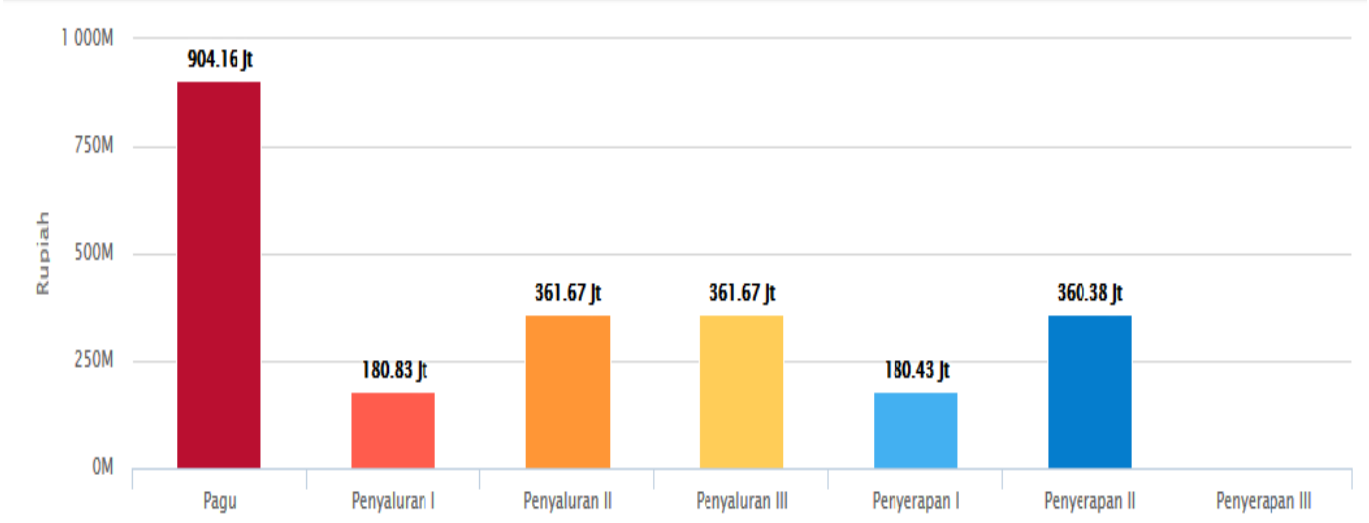

Sumber : Dinas Pemberdayaan Masyarakat, Desa, Kependudukan Dan Catatan Sipil Provinsi Jawa Tengah (2020)

\section{Tahapan Pengelolaan Keuangan Desa di Desa Kesongo}

Pengelolaan keuangan desa di Desa Kesongo diawali dengan tahap perencanaan, pelaksanaan, penatausahaan, dan tahap yang terakhir yaitu pelaporan dan pertanggungjawaban. Dalam tahap yang pertama yaitu perencanaan, tahap perencanaan diawali dengan Musyawarah Dusun atau biasa disebut dengan MusDus dalam MusDus berisi usulan-usulan yang bersifat rencana kerja tahun yaitu merencanakan rencana kerja jangka pendek, jangka menengah, dan jangka panjang yang diikuti oleh perangkat dusun, tokoh masyarakat, dan lembaga-lembaga desa, sehingga MusDus tahun ini adalah untuk merencanakan MusDus tahun selanjutnya. Hal ini sesuai dengan pernyataan yang disampaikan oleh Bapak B selaku tokoh masyarakat Desa Kesongo yang juga merupakan ketua Lembaga Pemberdayaan Masyarakat Desa (LKMD): "Perencanaan dimulai dengan tahapan pertama itu MusDus (Musyawarah Dusun) dalam MusDus itu ada usulan-usulan yang bersifat rencana kerja tahun, merencanakan jangka pendek, jangka menengah, jangka panjang” (Wawancara pada tanggal 22 Januari 2021). 
Usulan-usulan yang disampaikan di MusDus berangkat dari usulan masyarakat per RT yang sudah dimusyawarahkan dalam lingkup RT tersebut sehingga usulan dari masyarakat dapat tersampaikan mulai dari unit terkecil, musyawarah per RT ini dilaksanakan setiap 2 minggu sekali yang membahas salah satunya terkait dengan usulan yang akan disampaikan di MusDus, sehingga dalam MusDus ini membahas mengenai usulan dari masyarakat yang beragam kemudian disesuaikan dengan anggaran desa, jika dirasa anggaran yang dibutuhkan terlalu besar dan tidak sesuai maka kegiatan/pembangunan tersebut tidak bisa dilaksanakan, hasil dari keputusan MusDus ini akan ditulis dalam bentuk notulensi yang nantinya akan dibahas pada tahap selanjutnya yaitu Musengbangdes (Musyawarah Perncanaan Pembangunan Desa), dalam hal ini BPD sangat berperan karena mulai tahap awal MusDus harus ada pendampingan dari BPD bahkan BPD sebelum dilaksanakan MusDus sudah melakukan pertemuan rutin dengan RT/RW dan Pamong yang dilaksanakan setiap 4 bulan sekali sebagai bentuk komunikasi dan kerjasama antara pemerintahan desa. Hal ini sesuai dengan pernyataan yang disampaikan oleh Bapak NK selaku anggota Badan Permusyawaratan Desa (BPD) : "Jadi untuk MusDus itu kan kita musyawarah per dusun dulu, jadi ada aspirasi dari beberapa warga misalkan dari RT ini mengusulkan pembangunan ini, RT ini mengusulkan kegiatan ini, lha kita juga kan ada pendamping dari PemDes juga itu kan kita juga tau anggaran desa itu sekitar berapa nah itu pemerintah desa menyampaikan jadi kalau anggaran itu terlalu besar" (Wawancara pada tanggal 8 Maret 2021.

Masih ditahap perencanaan setelah dilakukan MusDus langkah selanjutnya adalah PraMusrengbang yaitu hasil dari MusDus di diskusikan antara BPD dan Pemerintah desa yang nantinya hasil tersebut akan dibawa ke Musrengbangdes agar keputusan di Musrengbangdes tidak terkesan tergesa-gesa dan keputusan yang diambil sudah melalui pemikiran yang matang, setelah itu baru dilaksanakan Musrengbangdes yang diikuti oleh tokoh masyarakat, perangkat desa, BPD dan lembaga-lembaga desa lainnya serta koramil, polsek atau babinsa, Musrengbangdes merupakan penggabungan dari MusDus yang sudah dilakukan per dusun, hasil dari Musrengbangdes ini ditulis dalam bentuk notulensi. Hal ini sesuai dengan yang disampaikan oleh Bapak NK selaku anggota BPD : "Di Musrengbangdes itu baru kita godok program-program mana yang dimasukkan dan program-program mana yang diprioritaskan"(Wawancara pada tanggal 8 Maret 2021).

Tahap selanjutnya yaitu Pelaksanaan, dalam tahap pelaksanaan ini yaitu implementasi dari apa yang sudah dimusyawarahkan dalam Musrengbangdes yang dilaksanakan oleh kelompok masyarakat yang dibuat oleh PemDes yang biasa disebut dengan PK (Pelaksana Kegiatan) dan TPK (Tim Pelaksana Kegiatan), anggaran dari bendahara desa diserahkan ke PK, dari PK diserahkan kembali ke TPK, anggota TPK merupakan seluruh kepala dusun ditambah tokoh masyarakat berjumlah ganjil, tugas dari TPK yaitu membelanjakan bahan yang akan digunakan dalam pelaksanaan kegiatan/pembangunan yang selanjutnya pembangunan/kegiatan tersebut akan dikerjakan oleh masyarakat Desa Kesongo sendiri yang biasa disebut PokJa (Kelompok Kerja). Hal ini sesuai dengan apa yang disampaikan oleh Bapak D selaku Sekretaris Desa Kesongo : "Uang dari bendahara desa disarahkan ke PK, dari PK menyerahkan lagi ke TPK. TPK nya itu adalah seluruh kepala dusun ditambah tokoh masyarakat berjumlah ganjil" (Wawancara pada tanggal 14 Januari 2021).

Tahap yang selanjutnya adalah Penatausahaan, ditahap penatausahaan ini TPK dengan arahan dari bendahara menyerahkan kwitansi, dan nota-nota sesuai dengan apa yang sudah dibelanjakan oleh TPK kepada bendahara sehingga TPK bertanggungjawab secara fisik maupun administrasi, setelah diserahkan kepada bendahara kemudian dicek ulang oleh koordinator kegiatan yang biasanya merupakan sekretaris desa sebelum diberikan kepada penanggung jawab yang merupakan Kepala Desa. Hal ini sesuai dengan apa yang disampaikan oleh Bapak B selaku tokoh masyarakat: "Nota-nota, kwitansi itu nanti dilaporkan ke tim pelaksana desa nanti diberikan kepada bendahara, ketua pokja melaksanakan kan ada anak buah itu yang belanja nanti diberikan ke TPK desa lalu di crosscheck" (Wawancara pada tanggal 22 Januari 2021).

Tahap yang ke-4 merupakan pelaporan, bendahara mulai menyusun laporan pertanggungjawaban terkait dengan kegiatan/pembangunan yang telah dilaksanakan yang disertai dengan lampiran berupa buktibukti seperti kwitansi dan nota, yang kemudian laporan tersebut nanti akan disosialisasikan kepada masyarakat, BPD dan lembaga-lembaga desa dan diserahkan ke kecamatan yang nantinya akan diproses ke 
otoritas yang lebih tinggi, laporan yang disampaikan sesuai dengan termin sesuai dengan cairnya anggaran. Hal ini sesuai dengan yang disampaikan oleh Bapak B selaku tokoh masyarakat yang juga merupakan ketua LKMD : "Ya ada kan yang dikerjakan itu laporan keuangan, itu kan berdasarkan termin jadi dana desa itu kan keluarnya ga sekali, termin pertama, termin kedua, termin ketiga gitu, ga sekali global, jadi laporan nanti ke BPD baru ke dinas gitu lho, jadi BPD itu harus tau wong dia yang mengesahkan anggaran kok" (Wawancara pada tanggal 22 Januari 2021).

Tahap yang terakhir yaitu pertanggungjawaban, diakhir tahun terdapat musyawarah desa pengesahan LRA (Laporan Realisasi APBDes) yang merupakan penyampaian pelaporan kegiatan baik yang terlaksana maupun yang tidak terlaksana, serta evaluasi kegiatan yang telah berjalan, dan penyampaian laporan realiasasi anggaran yang telah dilaksanakan, termasuk jika terdapat sisa anggaran akan disampaikan dalam LRA ini yang diikuti oleh BPD, Lembaga Desa serta perangkat desa, sebelum dilaksanakannya LRA BPD diberi data terkait dengan apa yang akan disampaikan di LRA agar dapat diperlajari sebelum LRA dilaksanakan, sehingga ketika LRA tidak terkesan tergesa-gesa. Hal tersebut sesuai dengan apa yang disampaikan oleh Bapak D selaku Sekretaris Desa Kesongo : "Namanya musyawarah desa pengesahan LRA (Laporan Realisasi APBDes), paling tidak dalam LRA itu kita menyampaikan seluruh kegiatan baik yang tidak terlaksana di tahun 2020 maupun kegiatan yang tidak terserap maksimal"(Wawancara pada tanggal 14 Januari 2021).

\section{Kearifan Lokal di Desa Kesongo}

Kearifan lokal yang ada di Desa Kesongo sangat beragam, namun pada penelitian ini kearifan lokal yang diangkat adalah budaya sadranan dan merti desa. Kedua budaya tersebut memiliki filosofi positif yang kemudian dijiwai oleh seluruh warga masyarakat di Desa Kesongo. Sadranan merupakan tradisi yang dilaksanakan untuk menyambut bulan ramadhan, dan dilaksanakan setiap 2 kali dalam setahun yaitu pada kalender jawa setiap bulan mulud dan rajab, sadranan ini dilaksanakan untuk penghormatan ke leluhur dan ahli waris yang dilaksanakan dengan membersihkan makam dan juga lingkungan sekitar termasuk di sumber mata air yang ada di Desa Kesongo, setelah itu masyarakat Desa Kesongo melakukan ritual tahlil, mendoakan leluhur yang telah meninggal, dan kemudian makan bersama di jalanan makam namun uniknya makanan yang dibawa ini merupakan makanan yang dibawa masing-masing masyarakat desa dan diikuti oleh seluruh masyarakat Desa Kesongo tanpa memandang umur dan gender. Hal ini sesuai dengan yang disampaikan oleh Bapak B selaku tokoh masyarakat: "Nyadran dilaksanakan setiap mau puasa, berfokus pada rohani, sadranan diikuti oleh seluruh masyarakat, merti desa diikuti oleh masyarakat mulai dari kecil, dewasa, laki laki, perempuan gitu lho"(Wawancara pada tanggal 22 Januari 2021).

Selaras dengan yang disampaikan oleh Bapak B, Bapak NR selaku anggota BPD Desa Kesongo juga menyampaikan hal yang serupa : "Sadranan itu kalau kita penghormatan ke leluhur ya jadi ke ahli waris, itu biasanya kan misalnya sadranan dusun ya kita itu bersih dusun"(Wawancara pada tanggal 8 Maret 2021). Sadranan ini selain sebagai penghormatan kepada leluhur juga sebagai ajang silaturahmi antar masyarakat, menjaga kekompakan dan kerukunan, dan pada kesempatan forum non-formal seperti ini biasa digunakan oleh PemDes sebagai ajang untuk menyampaikan informasi terkait perencanaan, pelaksanaan ataupun pertanggungjawaban, dengan adanya kearifan lokal yang salah satunya adalah sadranan ini memunculkan rasa kebersamaan yang terjalin antar masyarakat desa dan PemDes, karna adanya kebersamaan menimbulkan rasa saling percaya sehingga rasa egois dan individualis dapat terkesampingkan. Hal ini sesuai dengan yang disampaikan oleh Bapak B selaku tokoh masyarakat: "Nah kearifan lokal ini ada kalau terkait dengan itu, tapi kalau kearifan menyangkut yang lain kebudayaan itu bisa kita gunakan sebagai sarana sosialisasi betul, dengan adanya kebudayaan pertama itu kan bisa ajang silaturohim, pertemuan iya to mbak, bisa satu, bisa menyampaikan informasi"(Wawancara pada tanggal 22 Januari 2021).

Merti Desa merupakan acara yang dibuat sebagai bentuk pewujudan rasa syukur bahwa Desa Kesongo diberi tempat yang makmur, masyarakat yang sehat, dan permohonan agar diberi keselamatan. Merti Desa dilaksanakan setiap tahun namun setiap 2 tahun sekali acara merti desa ini dibuat dengan sangat meriah dengan mengundang dalang maupun ustad terkenal dibuat bergantian antara pentas kebudayaan seperti wayang kulit dan program keagamaan seperti pengajian, kegiatan ini juga disesuaikan dengan dana 
yang ada, kegiatan ini juga digunakan sebagai ajang penghormatan untuk para leluhur, perangkat desa dan pamong yang telah meninggal yang nantinya akan disebutkan dalam pengiriman doa dan tahlil. Hal ini sesuai dengan yang disampaikan oleh Bapak NR selaku Tokoh Masyarakat yang juga merupakan anggota BPD : "Merti Desa itu bentuk syukur kita bahwa di desa ini diberikan kesehatan diberikan tempat yang makmur itu ya biasanya disini juga seperti itu, selain kegiatan bersih-bersih lingkungan juga kita mengirimkan doa untuk leluhur-leluhur selain itu juga kegiatan-kegiatan budaya, dilaksanakan tiap tahun, jadi tiap tahun itu acara itu tetep ada tapi biasanya kalau yang besar itu 2 tahun sekali" (Wawancara pada tanggal 8 Maret 2021). Sama seperti Sadranan, Merti Desa juga sebagai ajang silaturahmi dan penyampaian informasi dan sosialisasi dari perangkat desa kepada masyarakat. Merti Desa ini diikuti pula oleh seluruh Masyarakat Desa Kesongo sehingga muncul sikap keterbukaan oleh perangkat desa dan kepercayaan oleh masyarakat.

\section{Kearifan Lokal dalam Pengelolaan Keuangan Desa di Desa Kesongo}

Nilai positif yang terkandung di dalam budaya sadranan dan merti desa dapat ditarik benang merah jika dikaitkan dengan pengelolaan keuangan desa di Desa Kesongo, khususnya di setiap tahapan pengelolaan keuangan desa. Di dalam tahap perencanaan, sadranan memuat nilai kesederhanaan, yang mempunyai filosofi agar warga desa dijauhkan dari sifat tamak yang dapat menyebabkan korupsi, sehingga dalam tahap perencanaan anggaran yang dibuat sesuai dengan kebutuhan tanpa dilebih-lebihkan selain itu juga mememuat nilai mandiri, filosofi yang terkandung adalah masyarakat membawa makanan sendiri untuk kenduri memiliki makna setiap masyarakat harus mampu berdiri di kaki nya sendiri, karena kemandirian sangat mempengaruhi sikap seseorang dalam mengambil tindakan baik tindakan baik maupun buruk, sehingga dalam tahap perencanaan diharapkan agar tidak mudah terpengaruh dalam hal buruk seperti penyelewengan dan korupsi dalam perencanaan anggaran. Hal tersebut disampaikan oleh Bapak NR selaku anggota BPD Desa Kesongo: "Makan bareng dalam bentuk sederhana ya seperti nyadranan, sadranan di sini itu ada yang dilaksanakan dijalan jadi ini makam memanjang dijalan itu dan uniknya, makanan yang dibawa itu ya dari masing-masing masyarakat itu jadi mereka datang ke situ bawa makanan sendiri” (Wawancara pada tanggal 8 Maret 2021).

Sementara merti desa dalam tahap perencanaan memiliki nilai keadilan yang memiliki filosofi bahwa apa yang dimiliki saat ini adalah milik Tuhan dan akan kembali kepada Tuhan, dan Tuhan tidak membeda-bedakan antara umat satu dengan yang lainnya, maka dari itu tidak sepatutnya kita sebagai manusia membeda-bedakan antar manusia satu dengan yang lain, hal ini dapat berperan dalam pengambilan keputusan kegiatan perencanaan yaitu dalam menentukan skala prioritas yang tepat tanpa mementingkan kepentingan individu maupun kelompok. Hal tersebut disampaikan oleh Bapak NR selaku anggota BPD Desa Kesongo : "Merti Desa itu bentuk syukur kita bahwa di desa ini diberikan kesehatan diberikan tempat yang makmur itu ya biasanya disini juga seperti itu, selain kegiatan bersih-bersih lingkungan juga kita mengirimkan doa untuk leluhur-leluhur selain itu juga kegiatan-kegiatan budaya" (Wawancara pada tanggal 8 Maret 2021).

Tahap pelaksanaan sadranan memuat nilai gotong royong yang mengandung filosofi bahwa dalam membersihkan makam maupun lingkungan sekitar dilakukan secara bersama-sama oleh seluruh warga Desa Kesongo, dalam tahap pelaksanaan juga dibutuhkan sikap gotong royong antar warga dengan pemerintah desa mulai dari pembelian bahan baku sampai dengan pelaksanaan pembangunan/kegiatan, dengan adanya sikap gotong royong maka kecurangan dan korupsi dapat diberantas karena sesuai dari tujuan gotong royong yaitu kesejahteraan, kebahagiaan, dan keselamatan bagi masyarakat Desa Kesongo. Hal tersebut disampaikan oleh Bapak NR selaku anggota BPD Desa Kesongo : "Sadranan dusun ya kita itu bersih dusun jadi bersih itu yang pertama di makam-makam itu, makam leluhur kita, orang tua kita dimakam itu ketika bersih-bersih setelah itu juga lingkungan masyarakat, dijalan, ditempat-tempat umum itu kita bersihkan setelah itu kita disitu melakukan ritual tahlil”.

Nilai Mandiri dalam sadranan juga dibutuhkan pada tahap pelaksanaan, filosofi yang terkandung adalah dalam sadranan masyarakat membawa sendiri makanan ke kenduri yang nantinya akan dimakan bersama-sama dengan masyarakat desa kesongo yang maknanya setiap masyarakat harus mampu berdiri di kaki sendiri, hal ini mengajarkan bahwa harus menjadi pribadi yang mandiri, tanpa bergantung kepada 
orang lain, karena kemandirian dapat mempengaruhi sikap seseorang dalam mengambil tindakan, dalam tahapan pelaksanaan ini perlu adanya sikap mandiri agar dalam pelaksanaan pembangunan/kegiatan dapat berjalan dengan efektif dan konstan tidak berubah-ubah sesuai dengan keputusan hasil musyawarah walaupun nantinya akan banyak pendapat dari berbagai pihak dan kelompok. Hal tersebut disampaikan oleh Bapak NR selaku anggota BPD Desa Kesongo : "Makanan yang dibawa itu ya dari masing-masing masyarakat itu jadi mereka datang ke situ bawa makanan sendiri" (Wawancara pada tanggal 8 Maret 2021).

Tahap penatausahaan dalam sadranan mengandung nilai gotong-royong, nilai ini dibutuhkan agar kerjasama antar bendahara dan TK maupun TPK dapat berjalan dengan baik tanpa adanya manipulasi nota ataupun kecurangan yang lain. Sementara merti desa dalam tahap perencanaan memiliki nilai kejujuran, filosofi yang terkandung yaitu akibat ketakutannya pada Tuhan maka memunculkan sikap kejujuran, dalam tahap penatausahaan kejujuran ini sangar penting yaitu dalam pelaporan nota dan kwitansi oleh TK dan TPK kepada bendahara. Hal tersebut disampaikan oleh Bapak NR selaku anggota BPD Desa Kesongo: "Merti Desa itu bentuk syukur kita bahwa di desa ini diberikan kesehatan diberikan tempat yang makmur" (Wawancara pada tanggal 8 Maret 2021).

Di dalam tahap pelaporan merti desa mengandung nilai kejujuran, karena ketakutannya akan Tuhan Yang Maha Esa, dalam tahap pelaporan jelas nilai kejujuran ini sangat penting dalam pembuatan laporan keuangan, agar yang disampaikan benar dan sesuai dengan realita begitu pula pada tahap pertanggungjawaban nilai kejujuran ini sangat dibutuhkan agar apa yang disampaikan benar adanya baik kegiatan yang terealisasi maupun tidak serta evaluasi-evaluasi yang diberikan. Hal tersebut disampaikan oleh Bapak NR selaku anggota BPD Desa Kesongo : "Merti Desa itu bentuk syukur kita bahwa di desa ini diberikan kesehatan diberikan tempat yang makmur" (Wawancara pada tanggal 8 Maret 2021).

\section{PEMBAHASAN}

Berdasarkan hasil penelitian yang telah disampaikan sebelumnya maka dapat terlihat bahwa nilainilai positif yang termuat di dalam kearifan lokal di Desa Kesongo, khususnya terkait dengan budaya sadranan dan merti desa dijiwai di dalam setiap tahapan pengelolaan keuangan desa. Lebih lanjut di dalam pembahasan ini akan menganalisis tentang keterkaitan antara kearifan lokal dan akuntabilitas pengelolaan keuangan desa. Merujuk bahwa secara umum tahapan pengelolaan keuangan desa telah dilaksanakan sesuai dengan aturan yang berlaku yaitu sesuai dengan Peraturan menteri dalam negeri Republik Indonesia nomor 20 (2018) yaitu perencanaan, pelaksanaan, penatausahaan, pelaporan dan pertanggungjawaban, ditambah dengan nilai-nilai positif di dalam budaya sadranan dan merti desa yang dijiwai di dalam melakukan pengelolaan keuangan desa, maka akuntabilitas dapat terwujud, hal serupa juga disampaikan oleh Darmada, D. K., Atmadja, A. T., dan Sinarwati (2016) bahwa akuntabiltas dan kearifan lokal setempat tidak dapat dipisahkan karena kearifan lokal berdampak positif bagi pertanggungjawaban laporan keuangan. Akuntabilitas yang dimaksudkan di sini adalah bentuk pertanggungjelasan kepada seluruh pemangku kepentingan, dalam hal ini adalah pemerintah desa, lembaga-lembaga desa serta seluruh masyarakat Desa Kesongo.

Secara umum kearifan lokal memiliki peran dalam mewujudkan akuntabilitas pengelolaan dana desa di Desa Kesongo, hal ini dikarenakan masih kentalnya tradisi yang ada di Desa Kesongo yaitu sadranan dan merti desa, tradisi-tradisi tersebut mengandung nilai-nilai luhur, seperti nilai sederhana yang memiliki filosofi bahwa warga Desa Kesongo supaya dijauhkan dari sifat tamak, nilai mandiri yakni setiap masyarakat harus mampu berdiri dikaki sendiri, nilai keadilan yang mengandung filosofi apa saja yang dimiliki saat ini merupakan milik Tuhan dan akan kembali kepada Tuhan, Tuhan tidak membeda-bedakan antara umat satu dengan yang lainnya, maka tidak sepatutnya kita sebagai manusia membeda-bedakan antar manusia satu dengan yang lainnya, selain itu juga terdapat nilai gotong royong dan kejujuran, hal tersebut merupakan bentuk kearifan lokal di Desa Kesongo.

Tradisi sadranan dan merti desa rutin dilaksanakan dan dijiwai oleh setiap masyarakat Desa Kesongo sehingga memunculkan kesadaran dari perangkat desa dan kepercayaan dari masyarakat Desa Kesongo, jika nilai-nilai luhur tersebut dijiwai dan terus dilaksanakan maka hal tersebut dapat mendukung terciptanya pertanggungjelasan kepada seluruh pemangku kepentingan dalam hal ini yaitu pemerintah desa, 
lembaga-lembaga desa dan seluruh masyarakat Desa Kesongo, dengan adanya kearifan lokal yang ada di Desa Kesongo selain untuk menjalin silaturahmi yaitu mendekatkan antar warga Desa Kesongo juga dijadikan forum diskusi oleh pemerintah desa dalam mensosialiasikan anggaran dana desa, hal tersebut sebagai salah satu upaya dalam mewujudkan akuntabilitas. Kepercayaan dan akuntabilitas memiliki kaitan yang erat karena akuntabilitas memiliki peran penting dalam meningkatkan kepercayaan masyarakat terhadap kegiatan yang sedang dirancang maupun sedang dijalankan oleh pemerintah desa untuk kepentingan masyarakat (Aziiz, 2019)

Sejalan dengan akuntabilitas dalam pengelolaan keuangan desa yang tercipta karena ada peran dari kearifan lokal yang ada, akuntabilitas publik ditekankan pada pemberian informasi kepada publik dan konstituen yang menjadi pemangku kepentingan (stakeholders) hal ini disampaikan oleh (Martini, 2019). Teori ini menyatakan bahwa berjalannya perusahaan bukan hanya untuk kepentingan pribadi atau kelompok namun harus bermanfaat pula bagi pemangku kepentingan yaitu merupakan pihak yang memberikan dukungan sehingga perusahaan dapat berjalan dengan baik (Deegan et al., 2000), yang berarti bahwa ketika pengelolaan keuangan desa di Desa Kesongo dilakukan secara akuntabel, maka tentunya akan meningkatkan kepercayaan dari seluruh pemangku kepentingan. Dengan menjiwai nilai-nilai kearifan lokal yang ada di Desa Kesongo, pemerintah desa berupaya untuk melibatkan masyarakat dalam berbagai pengambilan keputusan karena sesuai dengan teori stakeholder bahwa berjalannya pengelolaan dana desa bukan hanya untuk kepentingan pribadi/kelompok namun juga harus bermanfaat bagi pemangku kepentingan yaitu seluruh masyarakat Desa Kesongo maka setiap keputusan maupun pelaporan harus dapat dipertanggungjelaskan kepada masyarakat Desa Kesongo, hal ini dibuktikan dengan adanya MusDus dan Musrengbangdes yang merupakan bagian dari tahap perencanaan, yang berisi terkait dengan usulan-usulan masyarakat Desa Kesongo dan dimusyawarahkan bersama untuk mendapatkan skala prioritas yang akan dilaksanakan ditahapan selanjutnya dengan mengimplementasikan nilai-nilai kearifan lokal yaitu nilai sederhana, nilai mandiri dan nilai keadilan.

Di tahap pelaksanaan, panitia pelaksanaan juga diambil dari masyarakat Desa Kesongo sendiri dengan arahan oleh pemerintah desa, pelaksanaan dilaksanakan dengan menerapkan nilai-nilai kearifan lokal yaitu gotong royong dan mandiri, masyarakat juga ikut berperan ditahap penatausahaan yaitu notanota dan kwitansi bersumber dari TPK yang diberikan kepada bendahara, dengan menerapkan nilai-nilai dari kearifan lokal penyusunan pelaporan disusun dengan mengedepankan kejujuran dan gotong royong sesuai dengan nota dan kwitansi yang telah diberikan oleh TPK, di tahap pertanggungjawaban masyarakat juga dilibatkan dalam forum yang biasa disebut dengan LRA (Laporan Realisasi Anggaran), LRA ini berisi pelaporan pertanggungjawaban yang telah dilaksanakan maupun tidak serta evaluasi-evaluasi terhadap pembangunan/kegiatan yang telah dilaksanakan yang diikuti oleh Perangkat Desa, BPD dan Tokoh Mayarakat.

Dalam forum-forum non formal seperti sadranan dan merti desa juga di manfaatkan oleh pemerintah desa untuk diskusi dan sosialisasi terkait anggaran dana desa maupun pembangunan/kegiatan yang akan dilaksanakan sehingga seluruh masyarakat desa dapat berpartisipasi, hal tersebut memunculkan kepercayaan dari masyarakat Desa Kesongo kepada pemerintah desa, serta memunculkan kesadaran dari pemerintah untuk berlaku jujur, karena norma-norma kearifan lokal yang kuat, yang salah satunya yaitu adanya ewuh-pakewuh yang turun-temurun dan berkembang dimasyarakat jawa. Dengan masyarakat dilibatkan dalam berbagai forum pengambilan keputusan dan pertanggungjawaban, hal tersebut merupakan wujud pertanggungjelasan dari Pemerintah Desa kepada masyarakat Desa Kesongo.

\section{KESIMPULAN}

Berdasarkan penelitian yang telah dilakukan dapat disimpulkan bahwa pengelolaan dana desa di Desa Kesongo sudah dilakukan sesuai dengan Permendagri Nomor 20 Tahun 2018 tentang Pengelolaan Keuangan Desa yaitu tahap perencanaan, pelaksanaan, penatausahaan, pelaporan, dan pertanggungjawaban. Kearifan lokal di Desa Kesongo memiliki nilai-nilai luhur dan positif yang jika dijiwai dan diimplementasikan di setiap tahapan pengelolaan keuangan desa maka akan mendukung terwujudnya akuntabilitas pengelolaan keuangan desa di Desa, hal ini sesuai dengan visi dan misi Kabupaten Semarang yaitu prinsip good governance yang salah satunya terkait akuntabilitas. 
Jurnal Proaksi, 8 (2), Hal 400 - 416

\section{SARAN}

1. Saran teoritis terkait dengan peran kearifan lokal yang mampu mendukung terwujudnya tata kelola desa yang baik, dengan salah satu pilarnya adalah akuntabilitas.

2. Saran praktis bahwa kearifan lokal di Desa Kesongo perlu dipertahankan, karena memiliki peran penting dalam terwujudnya akuntabilitas keuangan desa, sedangkan realita yang terjadi saat ini kearifan lokal justru mulai luntur karena masuknya budaya luar yang berkembang di kalangan anak muda saat ini sehingga nilai positif yang terkait dengan kearifan lokal di suatu daerah tertentu semestinya perlu untuk terus dilestarikan dan ditanamkan kepada generasi muda.

\section{KETERBATASAN PENELITIAN}

Dalam penelitian ini yaitu hasil penelitian tidak dapat di generalisasikan karena hanya dilakukan di satu objek penelitian saja sehingga akan terdapat perbedaan kearifan lokal yang mengandung nilai-nilai luhur, serta perilaku di objek penelitian yang lain karena setiap daerah memiliki tradisinya masing-masing yang mengakibatkan hasil penelitian ini tidak dapat menggambarkan bahwa nilai kearifan lokal sudah pasti dapat berperan dalam mewujudkan akuntabilitas pengelolaan keuangan desa, karena tidak semua yang terkandung dalam kearifan lokal dapat mendukung terwujudnya akuntabilitas pengelolaan keuangan desa. Berdasakan keterbatasanan dari penelitian ini, saran yang untuk penelitian selanjutnya adalah dapat dilakukan penelitian di objek penelitian yang lain dengan budaya yang berbeda dengan budaya Jawa, contohnya seperti budaya yang ada dibali yang terkenal dengan Tri Hita Karana maupun budaya lainnya di berbagai daerah di nusantara.

\section{REFERENSI}

Akbar, A. (2020). Mendagri minta aparat desa jaga akuntabilitas dana desa. Retrieved from Antara.News website: https://www.antaranews.com/berita/1288342/mendagri-minta-aparat-desa-jaga akuntabilitas-dana-desa

Astuti, T. P., \& Yulianto, Y. (2016). Good governance pengelolaan keuangan desa menyongsong berlakunya Undang-Undang No. 6 Tahun 2014. Berkala Akuntansi Dan Keuangan Indonesia, 1(1), 1-14. https://doi.org/10.20473/baki.v1i1.1694

Aziiz, M. N. (2019). Faktor - Faktor yang Mempengaruhi Akuntabilitas Dana Desa. 6, 334-344.

Dahnur, H. (2020). Laporan fiktif dana desa Rp260,7 juta, seorang bendahara ditahan polisi. Retrieved from Kompas.Com website: https://regional.kompas.com/read/2020/02/20/06514051/laporan-fiktif-danadesa-rp-2607-juta-seorang-bendahara-ditahan-polisi

Darmada, D. K., Atmadja, A. T., \& Sinarwati, N. (2016). Kearifan Lokal Pade Gelahang dalam Mewujudkan Integrasi Akuntabilitas Pengelolaan Keuangan Organisasi Subak. Jurnal Akuntansi Multiparadigma. https://doi.org/https://doi.org/10.18202/jamal.2016.04.700 4

Deegan, C., Rankin, M., \& Voght, P. (2000). Firms' disclosure reactions to social incidents: Australian evidence. Accounting Forum, 24(1), 120.

Dinas Pemberdayaan Masyarakat, Desa, K. D. C. S. P. J. T. (2020). SIDesa Jawa Tengah. Retrieved from DISPERMADESDUKCAPIL PROV. JATENG website: https://sidesa.jatengprov.go.id/desa/33.22.06.2007

Fachreinsyah, fachreinsyah. (2020). Kepala Desa harus transparan dan akuntabel mengelola dana desa. Retrieved from rri.co.id website: https://rri.co.id/ekonomi/775643/kepala-desa-harus-transparan-danakuntabel-mengelola-dana-desa

Freeman, R. E. (1984). Strategic Management: A Stakeholder Approach. Boston: Pitman.

Gray, R., Dey, C., Owen, D., Evans, R., \& Zadek, S. (1997). Struggling with the praxis of social accounting: Stakeholders, accountability, audits and procedures. Accounting, Auditing \& Accountability Journal, 10(3), 325-364. https://doi.org/10.1108/09513579710178106

Hanum, F. (2019). Akuntabilitas keuangan desa (studi kasus Desa Ngentrong Kecamatan Karangan Kabupaten Nganjuk). Jurnal Mediasosian : Jurnal Ilmu Sosial Dan Administrasi Negara, 2(1), 5156. https://doi.org/10.30737/mediasosian.v2i1.207 
Harjito, Y., Wibowo, A. C., \& Suhardjanto, D. (2016). Telaah Kearifan Lokal Terhadap Akuntabilitas Lumbung Desa. Jurnal Ekonomi Dan Bisnis, 18(1), 69. https://doi.org/10.24914/jeb.v19i1.481

Indriani, C. (2020). Polisi selidiki 7 kasus dugaan penyelewengan BLT Covid-19 di Riau. Retrieved September 21, 2020, from Kompas.Com website: https://regional.kompas.com/read/2020/07/15/21392491/polisi-selidiki-7-kasus-dugaanpenyelewengan-blt-covid-19-di-riau?page=all

Karang, A. M. (2020). Kades di Garut diduga korupsi dana desa, diamankan kejari. Retrieved from Kompas.Com website: https://regional.kompas.com/read/2020/03/19/18033011/kades-di-garutdiduga-korupsi-dana-desa-diamankan-kejari

Kementerian Keuangan Republik Indonesia. (2021). Anggaran dana desa, 2015-2020. Retrieved from http://www.djpk.kemenkeu.go.id/wp-content/uploads/2021/02/Kebijakan-Dana-Desa-2021.pdf

Koentjaraningrat. (2009). Pengantar ilmu antropologi. Jakarta: Aksara Baru.

Latuconsina, Y. M., \& Soleman, K. (2019). Identifikasi nilai-nilai kearifan lokal pencegah tindakan fraud dalam pengelolaan keuangan desa di Kecamatan Leihitu. Jurnal Maneksi, 8(2), 235-241. Retrieved from http://www.ejournal-polnam.ac.id/index.php/JurnalManeksi/article/viewFile/395/252

Lestari, A. K. D., Atmaja, A. T., \& Adipura, M. P. (2014). Membedah Akuntabilitas Praktik Pengelolaan Keuangan Desa Pakraman Kubutambahan, Kecamatan Kubutambahan, Kabupaten Buleleng, Provinsi Bali (Sebuah Studi Interpretif Pada Organisasi Publik Non Pemerintahan). JIMAT (Jurnal Ilmiah Mahasiswa Akuntansi S1), 2(1). https://doi.org/10.23887/jimat.v2i1.2252

Mardiasmo. (2002). Akuntasi sektor publik, (2nd ed.). Yogyakarta: Andi.

Mardikanto, T. (2014). SR (Corporate Social Responsibility) (Tanggung Jawab Sosial Perusahaan). Bandung: Alfabeta.

Martini, R. (2019). Sistem Pengendalian Intern Pemerintah Atas Akuntabilitas Pengelolaan Keuangan Dana Desa Di Kecamatan Sembawa. Jurnal Akademi Akuntansi, 2(1), 106-123. https://doi.org/10.22219/jaa.v2i1.8364

Masriadi, M. (2020). Gelapkan dana desa hingga Rp325 juta, Kepala Desa di Aceh utara diamankan polisi. Retrieved from Kompas.Com website: https://regional.kompas.com/read/2020/02/23/17010291/gelapkan-dana-desa-hingga-rp-325-jutakepala-desa-di-aceh-utara-diamankan

Musafiri, M. . Al, Utaya, S., \& Astina, I. . (2016). Integrasi nilai-nilai kearifan lokal suku using dalam pendidikan karakter sekolah menengah atas. 258-270.

Nafidah, L. N., \& Anisa, N. (2017). Akuntabilitas pengelolaan keuangan desa di Kabupaten Jombang. Akuntabilitas, 10(2), 273-288. https://doi.org/10.15408/akt.v10i2.5936

Pemerintah Desa Sumberagung. (2017). Sadranan: Bukan musrik, hanya untuk mengingat leluhur. Retrieved from Soloweb website: https://sumberagung-klego.desa.id/berita-4Sadranan..Bukan.Musrik..Hanya.Untuk.Mengingat.Leluhur.html

Peraturan menteri dalam negeri Republik Indonesia nomor 20. (2018). Peraturan menteri dalam negeri Republik Indonesia nomor 20 tahun 2018 tentang pengelolaan keuangan desa. Kementrian Dalan Negeri Republik Indonesia.

Peraturan Pemerintah nomor 60. (2014). Peraturan Pemerintah nomor 60 Tahun 2014 tentang Dana Desa (pp. 1-25). pp. 1-25.

Peraturan Pemerintah Republik Indonesia. (2000). Peraturan pemerintah Republik Indonesia nomor 101 tahun 2000 tentang pendidikan dan pelatihan jabatan. 130-139.

Permata, R. E., \& Hapsari, A. N. S. (2020). Kearifan lokal dalam pengelolaan dana desa. AFRE (Accounting and Financial Review), 3(1), 43-58. https://doi.org/10.26905/afr.v3i1.4294

Putra, D. (2013). Pengaruh akuntabilitas publik dan kejelasan sasaran anggaran terhadap kinerja manajerial satuan kerja perangkat daerah.

Rahmatiani, L. (2016). Nilai kearifan lokal sunda sebagai basis tata kelola pemerintahan yang baik (Good Governance). $\quad$ Civics, $1(1), \quad 81-88 . \quad$ Retrieved from http://journal.ubpkarawang.ac.id/index.php/PPKn/article/view/30

Rahyono, F. X. (2009). Kearifan budaya dalam kata. In Wedatama Widyasastra. Jakarta. 
Jurnal Proaksi, 8 (2), Hal 400 - 416

Riyanto, T. (2015). Akumtabilitas finansial dalam pengelolaan Alokasi Dana Desa (ADD) di kantor desa perangkat selatan kecamatan marangkayu kabupaten Kutai Kartanegara. Ejournal Administrasi Negara, 3(1), 119-130.

Saputra, K. A. K., Sujana, E., \& Tama, G. M. (2018). Perspektif budaya lokal Tri Hita Karana dalam pencegahan kecurangan pada pengelolaan dana desa. Jurnal Akuntansi Publik.

Sarono, A. H. (2020). Hasil korupsi dana desa hilang dibawa kabur penipu berkedok dukun pengganda uang. Retrieved from Kompas.Com website: https://regional.kompas.com/read/2020/03/11/16013901/hasil-korupsi-dana-desa-hilang-dibawakabur-penipu-berkedok-dukun-pengganda

Sartini. (2004). Menggali kearifan lokal nusantara sebuah kajian filsafati. Jurnal Filsafat, 37(2), 111-120. Retrieved from https://jurnal.ugm.ac.id/wisdom/article/view/33910/20262

Setiawan, A., Haboddin, M., \& Wilujeng, N. F. (2017). Akuntabilitas Pengelolaan Dana Desa di Desa Budugsidorejo Kabupaten Jombang Tahun 2015. Politik Indonesia: Indonesian Political Science Review, 2(1), 1. https://doi.org/10.15294/jpi.v2i1.8483

Sibarani, R. (2012). Kearifan lokal: hakikat, peran, dan metode tradisi lisan. Asosiasi Tradisi Lisan (ATL).

Sukmayadi, T. (2017). Pendidikan karakter berbasis nilai nilai kearifan lokal melalui ajaran "Pamali" pada masyarakat adat kampung Kuta kabupaten Ciamis. Edukasi Islami, 05(1).

Umarmi, \& Amiruddin. (2014). Pengelolaan lingkungan berbasis kearifan lokal. Yogyakarta: Aditya Medai Publishing.

Undang-Undang Republik Indonesia Nomor 6 Tahun 2014. (2014). Undan-Undang Republik Indonesia Nomor 6 Tahun 2014 Tentang Desa. https://doi.org/10.1145/2904081.2904088

Utami, I. (2019). Audit internal:pendekatan kontemporer.

Wibisono, N. (2017). Mengungkap Fenomena Pengawasan Publik Terhadap Dana Desa di Kabupaten Madiun. 2, 8-19.

Wida, S. A., Supatmoko, D., \& Kurrohman, T. (2017). Akuntabilitas pengelolaan Alokasi Dana Desa (ADD) di desa - desa kecamatan Rogojampi kabupaten Banyuwangi. E-Journal Ekonomi Bisnis Dan Akuntansi, 4(2), 148. https://doi.org/10.19184/ejeba.v4i2.5356

Yulianah, Y. (2017). Potensi penyelewengan alokasi dana desa di kaji menurut peraturan menteri dalam negeri nomor 37 tahun 2007 tentang pengelolaan keuangan desa. Jurnal Hukum Mimbar Justitia, 1(2), 608. https://doi.org/10.35194/jhmj.v1i2.43

Zeyn, E. (2011). Pengaruh penerapan good governance dan standar akuntansi pemerintahan terhadap akuntabilitas keuangan. Trikonomika, 10(1), 52-62. 